\title{
Servando Teresa de Mier y la escritura de la historia de la revolución. Usos políticos del criollismo*
}

\author{
Servando Teresa de Mier and the \\ Writing of the History of the Revolution: \\ Political Uses of Criollismo
}

\author{
Mariana Inés Rosetti ${ }^{* *}$ \\ (D) https://orcid.org/0000-0003-0164-1224 \\ Universidad de Buenos Aires, Argentina \\ Instituto de Literatura Hispanoamericana \\ marurosetti@gmail.com
}

Resumen: En este trabajo indagamos las claves de la escritura que Servando Teresa de Mier propuso y desplegó en su obra Historia de la revolución de la Nueva España (1813) tendentes a construir una trama narrativa americana que editó documentos y perspectivas peninsulares sobre la capacidad de representación política americana. Más que defender una revolución institucional ante otra insurgente y popular, el mérito de Mier residió en proponer, inventar, un archivo americano o memoria colectiva americana que vinculó los tiempos de la conquista española con los tiempos políticos y vertiginosos inaugurados a partir de 1808 y ampliar ese discurso a fin de abarcar a todos los sectores "desprotegidos" de América.

* El artículo fue financiado, como figura, con una beca posdoctoral del Conicet.

** Becaria posdoctoral de Agencia del Centro de Historia Intelectual de la Universidad Nacional de Quilmes e investigadora en el Instituto de Literatura Hispanoamericana de la Universidad de Buenos Aires.

cómo citar: Rosetti, M. I. (2021). Servando Teresa de Mier y la escritura de la historia de la revolución. Usos políticos del criollismo. Secuencia (109), e1730. DoI: https://doi.org/10.18234/secuencia.v0i109.1730

cc $(1)$ Esta obra está protegida bajo una Licencia Creative Commons Atribución-NoComercial 4.0 Internacional. 
Palabras clave: Servando Teresa de Mier; Historia de la revolución de Nueva España; emancipación novohispana; criollismo; discurso histórico.

Abstract: In this article, we explore the writing devices Servando Teresa de Mier proposed and used in his book Historia de la revolución de la Nueva España (1813), designed to construct an American narrative plot that edited documents and peninsular perspectives on the capacity for American political representation. Rather than defending an institutional revolution against another popular, insurgent one, Mier's merit lay in proposing and inventing an American archive or collective memory that linked the time of the Spanish conquest with the dizzying political times that began in 1808 and expanded this discourse to encompass all the "unprotected" sectors of America.

Key words: Servando Teresa de Mier; Historia de la revolución de Nueva España; Novo-Hispanic emancipation; criollismo; historical discourse.

Recibido: 21 de marzo de 2019 Aceptado: 8 de noviembre de 2019

Publicado: 26 de enero de 2021

\section{INTRODUCCIÓN: RÁFAGAS DE LUZ EN LA HISTORIA POLÍTICA AMERICANA***}

Si conociesen bien la religión de Jesucristo, ¿hubiera podido el fanatismo, saliendo rabioso de entre los palacios godo-episcopales y las cavernas de la Inquisición, añadir su tea funesta a las llamas de la guerra civil, y hacer mirar como herejes y excomulgados a los que rehusaban arrodillarse como viles esclavos ante el simulacro sangriento de los déspotas? Eran menester pues soltarle al paso algunas

\footnotetext{
*** Agradezco las sugerencias y observaciones del doctor Iván Escamilla sobre el uso del discurso histórico que hizo Servando Teresa de Mier en vínculo con las problemáticas del siglo XVIII americano. A su vez, agradezco la lectura minuciosa y muy valiosa de los evaluadores de este artículo quienes han sugerido modificaciones sumamente útiles de la versión anterior del artículo.
} 
ráfagas de luz y oponer a los rayos espirituales algunas barras eléctricas.

Fray Servando Teresa de Mier (1990, p. 12).

E n este artículo nos proponemos analizar el entramado narrativo ${ }^{1}$ que practica Servando Teresa de Mier en su Historia de la revolución de 1813 al actualizar la retórica criollista, a mitad de camino entre la discursividad política moderna y la discursividad tradicional del antiguo régimen. Consideramos que la propuesta de Mier excede el carácter restaurador de una apologética historia eclesiástica (Domínguez Michael, 2004) o la reconstrucción de un discurso reivindicador de los derechos de prelación criollos (Garriga, 2003, 2006). Más que defender una revolución institucional ante otra insurgente y popular (Annino, 2008), el mérito de Mier residió en adaptar el discurso identitario-cultural del discurso criollo a los tiempos políticos y vertiginosos inaugurados a partir de 1808 y ampliar ese discurso a fin de abarcar a todos los sectores "desprotegidos" de las Américas. Dentro de la trama que propuso este letrado, no nos es posible escindir la búsqueda de representación política y cultural americanas de los procesos de insurgencia o de los debates constitucionales gaditanos. Por estos motivos, consideramos necesario abordar el análisis desde una metodología interdisciplinaria que recurra al análisis discursivo y retórico, a la historia conceptual y a la historia cultural con el fin de acercarnos y analizar correctamente los usos de conceptos como revolución y americanos que utilizó y actualizó Mier en su narrativa histórica en diálogo con su contexto de producción y los destinatarios de esta obra. ${ }^{2}$

En su Historia, Mier puso a disposición y contextualizó muchos documentos sobre los levantamientos americanos contra la monarquía española, sesiones de las Cortes de Cádiz, informes militares españoles y artículos periodísticos: "el lector debe alegrarse de hallar reunido lo que apenas encontraría con trabajo en muchos papeles” (Mier, 1990, p. 11). La organización de los

1 "Por tramado entiendo simplemente la codificación de los hechos o contenidos en las crónicas como componentes de tipos específicos de estructura de tramas” White (2003, p. 112).

2 "Fray Servando dedica varias páginas al tema de la mediación inglesa, mecanismo político que podría beneficiar a los americanos, pues está convencido que los ingleses quieren por conveniencia (más que por otra cosa) la independencia americana; sin embargo, no se deciden contrariar al gobierno español a causa de la situación político-militar que Napoleón ha provocado en Europa" (Breña, 2005, p. 86). 
capítulos es caótica no sólo porque responde a problemáticas distintas que incluyen una respuesta polémica a Juan López Cancelada, una recopilación de los sucesos acaecidos en los levantamientos en Nueva España de Hidalgo y de Morelos a partir de 1810 y las dificultades y luchas de los representantes americanos en las Cortes de Cádiz, entre otros sucesos. Si bien esta obra es reconocida especialmente por su libro XIV (en el que dedica una buena parte al estatuto de las posesiones españoles del Nuevo Mundo y a los derechos de los americanos a través de la propuesta de una "magna carta americana existente en el Código de las Indias") (Mier, 1990, p. 11), lo cierto es que todo el texto maneja una trama narrativa polémica y en vínculo directo con el funcionamiento dinámico de la opinión pública. En otras palabras, en esta publicación Mier planteó una lectura de la historia de la revolución novohispana cuando este proceso no se había consolidado ni disipado. Para este letrado criollo la escritura de la historia debía servir como marco de lectura o repositorio de las distintas novedades que circulaban, especialmente en la prensa periódica londinense, gaditana y americana. El discurso histórico no estaba escindido del funcionamiento recopilador y editor de la prensa sino en plena sintonía con las estrategias que manejaban los publicistas del periodo, entre los que cuenta con los modelos de José Blanco White y Juan López Cancelada como sus interlocutores por excelencia (Rosetti, 2016). Según Mier (1990), "era pues necesario [...] proveer a mis paisanos de un manualito de exorcismos” (p. 13). Por tanto, este letrado se propuso aportar ráfagas de luz a la historia de la conquista española para revisarla y cuestionarla. Los hechos recientes, simultáneos en el caso del levantamiento de Morelos, le sirvieron a Mier como puente para ir y venir entre la conquista española y la búsqueda de representación política de los novohispanos en la crisis de la monarquía española.

\section{EL DISCURSO HISTÓRICO Y LA TRAMA NARRATIVA AMERICANA}

En el año 1813 Servando Teresa de Mier publicó con el seudónimo de José Guerra su Historia de la revolución de la Nueva España antiguamente llamada Anáhuac o Verdadero origen y causas de ella con la relación de sus progresos hasta el presente año en la ciudad de Londres. Esta obra situó e inscribió a la insurgencia encabezada por Miguel Hidalgo en Nueva España en 1810 como el levantamiento ante un suceso de actos de injusticia y violencia sufridos por los 
americanos producto de una decadente monarquía española. ${ }^{3}$ Mier recurrió al discurso histórico para denunciar injusticias sufridas por los americanos y contextualizó los hechos pensando en lectores ingleses de los cuales buscaba el apoyo para su intervención en América. ${ }^{4}$

Este escrito fue solicitado y financiado en una primera etapa por la esposa del virrey José de Iturrigaray (1742-1815). El acercamiento de la familia Iturrigaray con Mier (al igual que otros letrados novohispanos) durante su estadía en Cádiz se debió a motivos de orden jurídico-moral: el exvirrey necesitaba limpiar su nombre de toda trama de complot o rebeldía separatista americana y, a su vez, denigrar a sus opositores políticos que realizaron un golpe institucional al derrocarlo. En otras palabras, la esposa de Iturrigaray le solicitó a Mier el armado de una apología de la figura del virrey recientemente destituido por el golpe de Estado liderado por el comerciante Yermo y producto de la coalición de la Audiencia y el Consulado de México en el mes de septiembre de 1808. El exvirrey había sido deportado junto con su familia a España y esperaba los juicios de residencia y de infidencia. A pesar de haber sido indultado por el cargo de infidencia en 1809, el juicio de residencia siguió en pie y tuvo su veredicto en 1815 , año en el que el exvirrey falleció. ${ }^{5}$

La obra de Mier consta de catorce libros de los cuales sólo los primeros siete refutan la versión difamatoria sobre el exvirrey Iturrigaray concentrada

${ }_{3}$ Al respecto, se sugieren los estudios de Annino (2008); Brading (1980, 1991); Domínguez Michael (2004); Goren (2011); O'Gorman (1981); Portillo Valdés (2006) y Rodríguez (1988). Destacamos las observaciones de Goren (2011) quien considera esta obra de Mier como pionera en la historiografía nacionalista mexicana: "Esta afirmación adquiere significado en dos sentidos: por una parte haciendo de los acontecimientos de los insurgentes una verdadera gesta nacional, rutilante de heroísmo, en la que Hidalgo y Morelos se convirtieron en figuras de magnas dimensiones que, desde entonces, han ocupado un lugar estelar en las historias de la independencia, $y$, por la otra, rescatando la historia prehispánica como parte integrante de la historia del país, haciendo seudoetimología de las palabras del náhuatl buscando de esa manera una continuidad cultural entre el mundo de antes de la conquista -al que llamó Anáhuac-y el actual-México-, intentando demostrar la igualdad de condiciones e incluso la superioridad del mundo indígena frente al mundo español” (p. 90).

${ }^{4}$ Esta postura crítica concibió la escritura histórica de forma instrumental para un lector inglés como un puente para producir cambios en América y fue abordada en la edición que coordinaron André Saint-Lu y Marie Cécile Bénassy Berling: "Mier quiere contestar a sus amigos americanos e ingleses, que le urgen para que continúe la Historia, porque desean un nuevo intento de mediación y le ofrecen documentos para restablecer la verdad" (citado en Mier, 1990, p. xxv).

${ }^{5}$ Para contextualizar los debates y pugnas institucionales de 1808 y el golpe de Gabriel de Yermo, destacamos las investigaciones de Ávila (2002); Lafuente Ferrarri (1941); Moreno (2004); Paniagua (2007, 2008); Torres Puga (2013); Zárate Toscano (1986, 2010), entre otros. 
en el escrito del periodista Juan López de Cancelada Verdad sabida y buena fe guardada, publicada en la ciudad de Cádiz el año de $1811 .{ }^{6}$ Sin embargo, el armado y los hechos que destacó Mier a lo largo de los distintos libros, específicamente en el xiv, mostraron la importancia que tenía el discurso historiográfico en el periodo independentista hispanoamericano. Este discurso unía y organizaba las distintas contiendas políticas que se desarrollaban tanto en la opinión pública peninsular y americana como en las Cortes de Cádiz sobre la capacidad de representación política americana y su madurez para valerse por sí misma en el contexto de crisis de legitimidad monárquica (Cañizares Esguerra, 1998, pp. 329-333; 2007, pp. 563-567). ${ }^{7}$ Al respecto, este letrado criollo concibió la escritura de la historia de la revolución novohispana como una forma de "asegurar la verdad" (Mier, 1990, p. 7) sobre los recientes sucesos revolucionarios acaecidos en distintas ciudades americanas. ${ }^{8}$ Para ello, seleccionó y analizó algunos hechos acaecidos en el periodo de 1810 a 1813 desestimando el valor rebelde endilgado a los escritos y actos populares o legislativos liderados por líderes criollos. En clave de lectura opuesta a la propuesta de López Cancelada, Mier construyó la verdad histórica como un arduo proceso de interpretación correcta y de puesta en diálogo de las fuentes documentales. Asumió, así, una lucha de interpretación de los panfletos, cartas, artículos periodísticos, edictos y escritos de guerra, entre otros textos, en los que se problematizaba la representación política de los americanos. Este procedimiento retórico-discursivo le permitió desplegar una lectura distinta de los hechos revolucionarios o insurgentes en tanto los entendía como sucesos de reivindicación de una representación política propia de los vasallos americanos que en nada perju-

${ }^{6}$ Luego de su detención y destierro de la ciudad de Nueva España, donde ejercía la labor de editor de la Gazeta de México (1805-1809), el periodista y comerciante Juan López de Cancelada publica en la ciudad de Cádiz este escrito en el que desea probar la "defensa de la fidelidad" del virreinato de Nueva España frente a la cruenta revolución que se gestó desde el año de 1808. Este escrito fue financiado por el Consulado de México y por ciertos comerciantes peninsulares residentes en Nueva España. Es interesante observar cómo en esta obra Cancelada concibe la rebelión popular de Hidalgo como continuación de una revolución novohispana iniciada por ciertos funcionarios criollos y que contó con la venia del exvirrey Iturrigaray.

7 "Cuando la guerra explotó, las facciones rivales lograron convertir una disputa por los derechos de representación política en las Cortes de Cádiz (1810-1814) en una disputa historiográfica, en donde los temas de credibilidad y autoridad se volvieron primordiales" (Cañizares Esguerra, 2007, p. 563).

${ }^{8}$ Todas las referencias a la Historia de la revolución de Mier se extraerán de la edición de 1990. Se modificó para este trabajo la grafía y ciertos usos gramaticales de la escritura de Mier para adaptarlas al uso gramatical actual. 
dicaba o desobedecía a la figura del rey Fernando VII. ${ }^{9}$ En continuación con la polémica letrada que había tenido con el sevillano José Blanco White (Breña, 2005; Moreno, 2015; Rosetti, 2014 y 2016), Mier resignificó los conceptos de revolución y de insurgencia. De esta forma, pensó estos conceptos desde un molde clásico retomado por la revolución francesa y ligado a la ciudadanía antigua que no implicó imitar las enseñanzas de los griegos o romanos, sino que vehiculizaba cambios con respecto al ejercicio de la representación política: ${ }^{10}$

Los franceses son los que han puesto en boga este término para designar a las naciones que se resisten a la violencia y usurpación. Y tienen razón, porque viene del verbo latín insurgo, que significa levantarse el que está caído, ponerse derecho. Con que verdaderamente es un título de honor en su origen y aplicación. Revolución viene del verbo revolvo, que en Cicerón significa volver otra vez o hacia atrás; con que si lo de atrás fuere mejor, la revolución será muy buena; así como el ponerse derecho si no hay cosa que rompa la cabeza. Las palabras no hacen nada (Mier, 1990, p. 13). [Cursivas mías].

Nos resulta fundamental este fragmento de la historia de Mier ya que resume los objetivos de escritura tendentes a refutar las versiones del Consulado de México y de los comerciantes peninsulares en Nueva España para priorizar una versión de la historia de la revolución en la cual el rectificar o reinterpretar los hechos implicaba para este letrado encauzarlos dentro de una trama narrativa que compilaba, editaba $y$, sobre todo, organizaba y transformaba las actas militares y las noticias periodísticas en elementos de la historia de la reivindicación americana y su propuesta de emancipación de España. Para Mier, "las palabras no hacen nada" si no iban acompañadas de un senti-

${ }^{9}$ Annick Lempérière (2008, p. 247) aclara que los hombres de letras no tenían en el periodo independentista a su disposición la palabra "secularización", ya que esta pertenecía ex oficio al vocabulario de las instituciones eclesiásticas. Sin embargo, plasmaron el concepto mediante el uso muy difuso de otros dos: "civilización" y "sociabilidad". Nos interesa la forma que tiene esta historiadora de plantear la secularización como el nuevo posicionamiento y conciencia del rol de los hombres de letras en el dominio y vehiculización de la palabra escrita e impresa.

10 "En rigor, para quienes propiciaban el resurgimiento de la Antigüedad durante la "época de la transición', en Europa como en América, imitar no era sino inventar” (Lomné, 2014, p. 389). En su interesante investigación, este historiador analiza las distintas sesiones de las Cortes en las cuales se recurre a las enseñanzas de ciudadanía clásica para concluir que se trata de una utilización de estas, pero con sentidos nuevos que se ajustaban a las problemáticas del periodo de guerra española contra los franceses y que dialogaba con intereses económicos de impronta liberal. 
do de lectura y de interpretación correctos que les permitiera a los receptores (sean americanos como ingleses) asir estos conceptos y utilizarlos como herramientas discursivas y actos políticos (Pasino, 2010).

En esta obra Mier insistió en los beneficios del discurso histórico en tanto lo entendía articulador de una trama narrativa que editaba los documentos y perspectivas peninsulares sobre América y que fundamentaba las capacidades de representación política de los americanos al mostrar el desconocimiento y yerros de autoridades españolas. ${ }^{11}$ Caracterizamos este tipo de trama como americana ya que, a lo largo de la obra, este letrado utilizó este atributo como noción elástica que traslada su significado desde un plano material-concreto (pertenencia a un territorio, geografía, clima y naturaleza) para pasar a designar una forma de ser particular tendente para formar una legitimidad comunitaria entre pares: "[N]o se trata de una villa o provincia, es el de todo un continente inmenso, o de la mitad del globo. No es el interés de un día, sino el de siglos" (Mier, 1990, p. 577). En el periodo en que Mier publicó su obra, esta particular forma de "ser americanos" era concebida como la apropiación político-cultural y, sobre todo, moral, de un locus de enunciación desde el cual muchos publicistas y letrados plantearon fuertes críticas al sector opositor y pretendieron convencer a sus lectores o acólitos sobre los pasos a seguir actuando en consecuencia a este atributo. Sostenemos que ciertos letrados criollos (como fueron los casos de José Miguel Guridi Alcocer, Carlos María de Bustamante y, particularmente, Servando Teresa de Mier) hicieron uso de este locus de enunciación para configurarse en guías del cambio político-social en su pasaje a una república todavía inexistente.

Por otro lado, la utilización del discurso histórico le permitió a este criollo entrelazar distintas tramas tales como la escritura apologética, el ensayo político, la manifestación o panfleto político, la carta entre pares letrados y estipular con estas materialidades escriturarias un armado discursivo transversal en el cual primaron las figuras retóricas de la ironía y la analogía. ${ }^{12}$ Es decir, esta "historia de las circunstancias" (Mier, 1990, p. 11) que

11 "Tengo la relación de lo ocurrido en todo el tiempo intermedio, que el mismo García Conde envió al Virrey [Venegas] desde Guanajuato en 13 de diciembre de 1810, y de ella me aprovecharé corrigiéndola o explicándola" (Mier, 1990, libro IX, p. 258). Este procedimiento editorial, de detener el informe, el documento o el relato de un opositor es usual en la narrativa de la historia de Mier y va de la mano del tono polémico de su escrito.

${ }^{12}$ Con respecto a la ironía, Linda Hutcheon (1992) sostiene: "[L]a ironía es esencial para el funcionamiento de la parodia y de la sátira, aunque de manera distinta. Dicho de otro modo, 
parecería no tener un plan de escritura preciso, ${ }^{13}$ recurrió a la ironía para desestimar las versiones críticas tanto criollas como peninsulares sobre los hechos de emancipación americanos. La ironía le resultó útil a Mier para transformar las versiones dadas por funcionarios, militares y periodistas americanos y peninsulares sobre los hechos insurgentes americanos en cuentos o fábulas propias de concurrentes de cafés de poca monta o malos lectores de la revolución francesa. Por otro lado, a contracara de la perspectiva irónica, este letrado utilizó el procedimiento retórico de la analogía para establecer un salto histórico o descendencia cultural estratégica mediante la cual concibió al sector criollo heredero directo de las injusticias político-sociales tanto de los conquistadores españoles como de los caciques indígenas mancillados por el proceso de conquista española. La analogía en Mier (1990) actuó como el puente de sentido necesario para estipular el linaje discursivo del discurso criollo:

[...] si los títulos que habéis alegado prueban algo, no prueban nada a favor de los españoles actuales, sino de los conquistadores nuestros padres; son títulos nuestros pues lo eran suyos, y vosotros queréis robárnoslos [...] Todo el género humano es originario de Asia, y nadie pretende por eso tener allá derecho, ni concedérselo a los asiáticos en las demás partes del mundo [...] Vosotros, para usurpar el título de apóstoles, habéis ocultado los vestigios evidentes de su predicación existentes en todas las Américas [...] al contrario de los Apóstoles hasta buscabais cierta analogía entre vuestros simulacros y los nuevos para sustituírselos (pp. 584-585).

En coincidencia con las observaciones de Garriga (2003), Cañizares Esguerra (2007) y Goren (2011), observamos que Mier recurre a la dualidad "peninsulares-americanos" iniciada por los reclamos de prelación del siglo XVI. Enunciación polémica reforzada por la discursividad clerical-criolla de

la ironía goza de una especificidad doble -semántica y pragmática- [...] La ironía es, a la vez, estructura antifrástica y estrategia evaluativa, lo cual implica una actitud del autor-codificador con respecto al texto en sí mismo. Actitud que permite y exige, al lector-descodificador, interpretar y evaluar el texto que está leyendo (pp. 175, 177).

13 "suplico al lector se contente con hallar la verdad según mi leal saber y entender, porque desde luego le confieso los defectos consiguientes no sólo a la pequeñez de mi talento y a la falta necesaria de plan, sino a la de reposo y de tiempo para digerirla mejor o darle la lima correspondiente" (Mier, 1990, p. 11). En burla a la caótica representación de los discursos y textos históricos esgrimida por Mier, Lorenzo Zavala sostuvo que se trató de un "escrito indigesto" (citado por O'Gorman en Mier, 1945, p. XIV). 
fines del siglo XVIII, caracterizada por Cañizares Esguerra como epistemología patriótica criolla. El fragmento seleccionado destaca la construcción de un locus de enunciación histórico-político problemático ya que sustenta la lucha política de emancipación a través de la retórica tradicional de filiación jurídico-política propia del antiguo régimen. En otras palabras, Mier estipuló una doble filiación político-social: los criollos son hijos tanto del rey Fernando VII como de los conquistadores y los caciques indígenas castigados por funcionarios coloniales corruptos. La salida del laberinto institucional de la monarquía española sólo podría darse a través del linaje discursivo que llevaría a los criollos de un padre político (el rey) a unos padres heroicos y nobles (los conquistadores y los caciques aztecas). Mier asumió este doble linaje como estrategia retórica para desestimar y condenar el legado católico impartido por los misioneros sobre los indígenas. El legado o transmisión del catolicismo fue concebido por la bula papal de Alejandro VI y por los diversos discursos jurídicos y, sobre todo, religiosos desarrollados a lo largo de los siglos XVI y XVII, como el pilar fundamental para justificar la conquista de América. Es este legado el que desestimó Mier y lo hizo a través de la creación de nuevos linajes discursivos que denunciaron las analogías perniciosas y destructivas que realizaron los primeros misioneros franciscanos en su afán de erradicar la idolatría y el canibalismo indígenas. Para lograr este objetivo, Mier configuró la propuesta independentista novohispana como acto justificado por las leyes y pactos sancionados entre la monarquía española y los nativos indianos:

[...] el de las Indias tenía tanto más motivo para reentrar en sus primitivos derechos en dicho caso, cuanto que aparecía jurídica y solemnemente roto por parte de los Reyes el pacto solemne celebrado con los conquistadores de Indias por los Reyes de Castilla y consignado en sus leyes de no ceder ni enajenar en todo ni en parte aquellos reinos para siempre so pena de ser nulo cuanto contra esto se ejecutasen (Mier, 1990, p. 33).

La labor metodológica de este letrado criollo novohispano consistió en despojar el concepto de revolución criolla de los ribetes rebeldes y caóticos con los que había sido caracterizada ya sea por los informes militares de los realistas como por la prensa novohispana y gaditana. En su lugar, Mier configuró discursivamente a los actos insurgentes novohispanos como un proceso de maduración y asunción de representación política, crecimiento guiado por una reflexión cívica y constitucional profundas: 
No por eso quiero decir que Hidalgo fuese un santo, ni santa la obra que emprendió. Aunque escribo en un país donde es una ley que todos los pueblos oprimidos tienen el derecho de levantarse contra sus opresores, que en el reino de Aragón en España la insurrección contra el gobierno que atacaba sus fueros y derechos era una parte de su Constitución [...] Déjese a la política retratar al vulgo en las gacetas monstruos que le espanten, hacer tuerto a José Napoleón con sus dos ojos claros; el historiador debe consultar a la verosimilitud y referir los hechos para que juzgue el lector sensato (Mier, 1990, libro IX, p. 268). [Cursivas mías].

En la cita, observamos cómo Mier estipula dos universos discursivos (la prensa/la historia) aparentemente escindidos y en pugna urgidos por tiempos de escritura, producción y público disímiles: mientras que la prensa se manejaría con la construcción de monstruos despóticos y lectores salvajes; la historia se destinaría a lectores sensatos con los cuales reflexionar sobre los hechos y los pasos a tomar para la configuración de la autonomía política buscada. Sin embargo, esta escisión fue una máscara estratégica de enunciación de Mier. La sensatez de la lectura histórica implicó en el proyecto de Mier la inclusión de las distintas voces americanas, peninsulares y europeas que proliferaban por la prensa y por la sala constitucional de las Cortes gaditanas. En especial, su obra histórica se construye en estrecho diálogo político-cultural con el periódico El Español (1810-1813) de José Blanco White (1775-1841) del cual extrajo (con la venia de su editor) cartas, proclamas, noticias americanas y posturas críticas elaboradas por el periodista sevillano sobre la necesaria intervención inglesa ante la inminente y conflictiva separación de las distintas colonias americanas de la monarquía española. ${ }^{14}$

Sostenemos que la articulación discursiva criolla de Mier concibió a la narrativa histórica como un laboratorio de experimentación, como dispositivo de concientización para sus destinatarios por contener una escritura desde la cual valorar y reinterpretar los hechos pasados. A su vez, esta escritura dialogó

${ }^{14}$ Resultan muy estimulantes y útiles las notas de Marie-Laure Rieu-Millan a la edición de La Sorbonne (1990), así como las observaciones que realizó sobre las cartas inéditas de Mier que descubre en archivos europeos (Rieu-Millan, 1982, 1989). En estos estudios, la historiadora reflexionó sobre la transformación de la postura combativa de Mier, con aristas jacobinas, al acercamiento a una mirada más liberal o whig que, sin embargo, no negó ni se alejó de su basamento discursivo patriótico criollo. Este acercamiento a las propuestas políticas de Blanco White fue buscado por Mier para facilitar la intermediación política y comercial inglesa, así como también buscó desestimar lecturas tendenciosas y negativas sobre la revolución americana construidas por la facción realista en Nueva España. 
con el género epistolar mayormente utilizado por los criollos desterrados de América y concentrados en Cádiz y Londres. Este género le brindó a Mier una forma de consolidar las ideas y propuestas políticas. ${ }^{15}$ Lejos de concebir esta historia como proyecto protonacionalista (como lo hace Brading, 1980) o pensarla como una escritura de moderación del espíritu jacobinista y de una propuesta de alianza político-económica con Gran Bretaña (Saint-Lu y Bénassy Berling, en Mier, 1990; Breña 2014), sostenemos que este letrado recurrió al discurso histórico como vía retórica para justificar la legalidad de la propuesta de los letrados criollos de fines del siglo XVIII y comienzos del XIx haciendo hincapié en la continuidad y la coherencia de tales propuestas. Las observaciones y denuncias de Mier no distan de las denuncias de explotación económica y corrupción política por parte de la monarquía peninsular que hicieron Juan Pablo Viscardo y Guzmán (1792) o Camilo Torres (1809) en sus escritos. A pesar de esta similitud de contenido de todos los escritos a cargo de letrados patriotas criollos, observamos en Mier la consciente estrategia de respaldar su tono denuncialista ligado a una retórica del desagravio criollo frente a las injusticias burocráticas vividas con el correr de los años coloniales (Altuna, 2009). A través de la construcción de un esqueleto histórico o trama narrativa histórica, Mier concibió la lucha político-cultural criolla como la lucha de representación política americana.

\section{MODOS DE LEER LA REVOLUCIÓN NOVOHISPANA: EL LECTOR SENSATO Y EL LECTOR SALVAJE}

En los capítulos Ix y x Mier (1990) planteó una equiparación entre la conquista española de América, la invasión francesa a España y la lucha del ejército realista en Nueva España para resaltar el salvajismo avant la lettre (libro x, pp. $274,281)$ que los militares españoles y franceses llevaron a cabo sin contemplar territorios ni poblaciones con los cuales se toparon. Estos dos capítulos cuestionaron el significado de la insurgencia americana y la contrapusieron al

15 Al respecto, se destacan la "Carta dirigida a los españoles americanos" de Juan Pablo Viscardo y Guzmán (1792) y las "Cartas americanas dirigidas por el conde Gian-Rinaldo Carli” (17771799). Cartas leídas de forma americanizada que fueron utilizadas como armas de guerra tanto por Francisco Miranda en su diálogo con el militar Manuel Gual (1799-1800) y en sus escritos durante su viaje a América (1806), como por Servando Teresa de Mier en su intercambio polémico con Blanco-White (1811-1812) y en su expedición libertadora de Londres a Nueva España que pergeñó con el militar Xavier Mina (1816) (Adelman, 2008; Brading, 2004; Breña, 2013; Padgen, 1990). 
salvajismo del accionar militar europeo, ligado a una obediencia ridícula rayana con la parodia. Se destacaron, así, argumentos que Mier retomó tanto de Antonio de Herrera (Historia general de los hechos castellanos en las islas y Tierra Firme del Mar Océano o descripción de las Indias Occidentales (1730), como de fray Bartolomé de Las Casas (Historia de las Indias (1562) tendentes a analizar el automatismo de los militares realistas que esgrimían el Requerimiento de 1513 . $^{16}$ Mier apeló para ello a un lector sensato y cómplice para burlarse de la autoridad de la facción realista en Nueva España. Parodió así los informes militares de los realistas para desacreditarlos al endilgarles su elaboración "a la francesa":

Supongo que el lector sabe lo que son los partes militares por lo común. Es una relación que por aproximación a lo ocurrido fragua el de la acción en su alojamiento, diciendo, para que se atribuya a su pericia, lo que debió hacer, si no lo hizo, para ganar la batalla, y si la perdió, fingiendo casualidades, achacando a otros la culpa, o al cansancio de sus tropas, aumentando las del enemigo [...] Especialmente después que Napoleón ha puesto en boga el burlarse así del mundo, los españoles en la América, por la semejanza de su causa, forman sus partes tan a la francesa que no merecen crédito alguno (Mier, 1990, libro x, p. 274).

La escritura de los partes militares, según Mier ridículamente copiados del quehacer militar francés, conllevó la risa de todo México a causa de la tergiversación de los hechos a manos de la facción realista, en especial los partes dictados por el brigadier D. Félix María Calleja. ${ }^{17}$ Este militar realista peninsular fue para Mier la representación contrahecha del terror militar francés ya que devino a sus ojos un lector salvaje del accionar militar francés: "[S]e debe confesar, en elogio de este y otros españoles, que aunque copian a cada paso

${ }^{16}$ Según David Brading (1980, p. 76), Mier construye en los libros IX al XI de su Historia de la revolución la segunda parte de la Brevísima relación de la destrucción de las Indias de Las Casas. Para lograr dicho objetivo Brading observa cómo Mier describe las acciones militares españolas que extrae de las gacetas oficiales.

Nuestra postura crítica se aleja de esta mirada de Brading, ya que vemos en la escritura de Mier la preocupación por la ambigüedad y la manipulación de la interpretación de los hechos insurgentes y revolucionarios plasmados en los informes oficiales realistas. Frente a esta manipulación burda, Mier planteó una lectura correcta y glorificada de las acciones insurgentes americanas.

${ }_{17}$ "el día 8 de noviembre, que la Gazeta publicó este parte, publicó también el de D. Félix Calleja sobre la victoria en Aculco contra los insurgentes, en que avisaba al Virrey había represado los dos cañones que quitaron a Truxillo en el Monte de las Cruces, México se rió a carcajadas de estas indecentes farsas" (Mier, 1990, libro x, p. 276). 
las proclamas amenazadoras de Murat, Soult y otros caníbales transpirenaicos, éstos, como franceses volubles, no tienen constancia para cumplirlas, pero aquéllos desempeñan su palabra con toda la honradez española" (Mier, 1990, libro X, p. 281).

La lectura salvaje del parte militar fue considerada por Mier como el corolario de la ruptura o desvío de una genealogía cultural peninsular, que proveniente de godos, romanos y moros, se interrumpió drásticamente. En su lugar, prevalecía un árbol genealógico de sangre impura que anhelaba una pureza racial, cultural y social:

Yo digo que si eso se llama matar a sus padres, los españoles mataron a los suyos en los moros y los están matando en los polacos e italianos, esto es, godos y romanos de quienes descienden. Los criollos tampoco podrán matar ayudando a los europeos, porque aquellas colonias europeas fueron de hombres y muy raras mujeres; tomaron las suyas en las familias Reales y nobles, y sería muy difícil a un criollo probar que no corre en sus venas la sangre pura de los aborígenes (Mier, 1990, libro IX, p. 271).

El procedimiento narrativo de estos dos libros buscó desestructurar la veracidad y autoridad de las denuncias públicas e informes militares peninsulares contra los americanos. El problema central sobre el cual reflexionó Mier a lo largo de su obra fue la ridícula distancia entre, por un lado, los derechos que los indios, criollos y castas americanos tenían en las Leyes de Indias y Constitución gaditana y, por otro lado, la salvaje interpretación de las autoridades peninsulares que cercenó los derechos de las leyes al aplicar un ejercicio despótico de estas. Para este letrado criollo el abismo existente entre las leyes y la práctica por las autoridades peninsulares prefiguró un caos insalvable a través de la vía legal que sólo podía ser subsanado por la vía de la emancipación de los reinos americanos. Esta lectura crítica sobre la fragilidad y obstrucción del aparato legal en América requería, para Mier, de una pronta respuesta de la monarquía española tendente a reconfigurar los lazos políticos reconociendo la representación política y económica de los americanos: "¡Pluguiese al cielo!, ciertamente no pediríamos que se mudase la antigua constitución de la monarquía, sino que se mejorase; no que se arrancasen las leyes fundamentales ni se destruyesen todas las nuestras, sino que se organizase el todo"(Mier, 1990, libro xIV, p. 525). 
Mier concibió a la escritura histórica de la revolución de Nueva España como el espacio propicio para plantear nuevos acercamientos a la identidad americana. Para lograrlo, propuso un abordaje que desestimó el valor esencialista para priorizar su sentido instrumental y político como herramienta para concientizar a sus lectores de la necesaria emancipación política. A lo largo de su escrito, este letrado novohispano sostuvo la importancia de construir una genealogía político-cultural americana que no se sostuviera solamente en tradiciones, autoridades o esencias abstractas, sino que también se actualizara y dirimiera en los textos y en los hechos. En otras palabras, sostenemos que la propuesta de escritura de Mier es novedosa al tomar al discurso histórico como texto polémico sobre el cual refutar la mirada peninsular, anquilosada y crítica, sobre la representación político-cultural americana:

¡Rebeldes!, exclaman. -Probadnos primero que somos vuestros súbditos, o por mejor decir, probad a los catalanes que son súbditos de los gallegos, o a los asturianos que son de los andaluces. Vosotros habéis proclamado la soberanía de la nación y nosotros componemos su mayor parte. Desde antes ya éramos independientes de vosotros por las leyes de Indias, ¿y vosotros no lo sois de nosotros? Si os obstináis en llamarnos rebeldes, no hacéis sino provocarnos a constituirnos en monarquía separada para arrancaros de una vez el pretexto de la insolencia con que llamáis rebeldes a los que son vuestros iguales (libro XIV, p. 580).

La propuesta de Mier se encuentra en sintonía con las lecturas estratégicas que construyeron distintos letrados criollos en la opinión pública novohispana con el correr del proceso de emancipación: "[L]o español americano o criollo que había surgido originalmente como un símbolo identitario regional y buscaba más bien una diferenciación cultural con respecto a lo español europeo o peninsular fue, a partir de 1808, una expresión ligada al mundo político y resignificada en él" (Moreno, 2004, p. 45). Es decir, Mier redefinió los conceptos de América/americanos contemplando las posibilidades retórico-discursivas que dejaron abierta y posibilitaron tanto la vacancia del poder real como la apertura jurídico-legal de las abdicaciones de Bayona y la invasión francesa de Napoleón: "América [...] jugó un importante rol discursivo en la Nueva España. Más que una realidad asible, el hemisferio fue una figura retórica, una especie de termómetro cuyas mediciones iban cambiando al ritmo de los acontecimientos" (Moreno, 2004, p. 37). 
Coincidimos y consideramos las propuestas críticas de Luis Villoro (1977); Rafael Rojas (2003); Rodrigo Moreno (2004); Antonio Annino (2008); José María Portillo Valdés (2006); Ivana Frasquet (2012) y Roberto Breña (2014) quienes destacan la dificultad del ejercicio de la representación política en Nueva España a causa del golpe de estado ocurrido en 1808 y la posterior insurgencia. Estos hechos generaron, según estos investigadores, un desplazamiento o desvío del ejercicio de la soberanía política de los novohispanos que se trasladó a las Cortes de Cádiz: "la construcción política de la Independencia tuvo que desarrollarse al margen de la sociabilidad representativa" (Rojas, 2003, p. 42). Al respecto, nos interesa cómo este desvío representativo ejerció en la labor histórica de Mier una redefinición del nombre americanos y una particular construcción del sintagma revolución americana. Ambas formaciones discursivas son resignificadas desde la modulación polifónica del criollismo. Este discurso utilizó una retórica de la restitución de la representación americana ya trabajada con anterioridad por jesuitas exiliados en el siglo XVIII (Padgen 1990, pp. 182-183), discurso que se recrudeció luego de las abdicaciones de Bayona en 1808. Estas propuestas criollas no implicaron necesariamente una postura crítica contra la monarquía o contra los españoles, sino contra el abuso de autoridad real (Entin 2013, p. 27) que se sostuvo en un ejercicio despótico de las leyes. Como bien lo observa Rodrigo Moreno (2004, p. 41), las propuestas de distintos letrados criollos (como Carlos María de Bustamante, José Miguel Guridi Alcocer, D. Jacobo de Villaurrutia, entre otros) buscaron crear y sostener discursivamente la fidelidad americana hacia la monarquía peninsular. Fidelidad particular ya que se construyó como una alianza criolla puramente discursiva y retórica.

\section{USOS POLÍTICOS DEL CRIOLLISMO}

En los libros viII y xIV de su historia, Mier reflexionó sobre el término revolución para dotarlo de un basamento político-cultural americano. Esta lectura justificó e incorporó los hechos revolucionarios dentro de una genealogía criolla ligada a los derechos de conquista de los cuales los criollos, herederos de padres conquistadores, podían hacer valer sus prerrogativas tanto sobre los territorios conquistados como sobre la administración burocrática novohispana.

La insistencia de Mier sobre un antiguo pacto entre los conquistadores y la monarquía española (avalado por la bula papal de Alejandro VI) dejó 
en evidencia el malestar americano dentro del engranaje burocrático-institucional. La propuesta de lectura de Mier manejó hábilmente variadas fuentes documentales (destacando ciertos fragmentos de las Leyes de Indias y de las representaciones, informes, quejas y propuestas que se publicaron en distintos periódicos europeos y se discutieron en las sesiones secretas de las Cortes de Cádiz a favor de la autonomía política americana y el reconocimiento político de todos sus habitantes). El conocimiento americano que manejaban los periodistas, folletinistas y gaceteros se basó en fuentes en pugna ya que, por un lado, ciertos periodistas como López Cancelada, presentaron opúsculos a las Cortes de Cádiz como La verdad sabida y la buena fe guardada (1811) o folletos anónimos como Quexas de los americanos (1812), escritos que interpretaron los sucesos revolucionarios americanos (en el caso de los documentos mencionados, sucesos novohispanos) como producto de acuerdos de ciertos sectores criollos con ciertos sectores populares. Estos escritos dialogaron con otras fuentes de corte científica e iluminista como fueron los estudios de De Pauw que retomaron ciertos diputados americanos (como Guridi Alcocer) para desestimar los postulados críticos sobre las tierras americanas y la vida de los americanos.

La selección precisa de leyes y documentos (periodísticos, informes militares, opúsculos, folletos) le permitieron a este letrado novohispano estipular una continuidad entre el derecho de representación política americana y la concreción de revoluciones para materializar este derecho. Su perspectiva sobre las acciones a tomar por los americanos pensó el accionar revolucionario como un vehículo necesario para la instalación de juntas locales que reconocieran la autoridad del monarca Fernando VII: "[N]o, no es de admirar que ésta sea la época de la erección de Juntas en América, sino la moderación y paciencia de sus habitantes, que no las formaron desde el primer sacudimiento de la metrópoli, que descuajó los cimientos de la monarquía, siendo ellos iguales a los peninsulares en derechos para representar a Fernando" (Mier, 1990, libro VIII, p. 224). La creación de Juntas fue guiada, según Mier, por motivos legislativos. ${ }^{18}$

La paciencia de los americanos con respecto a las autoridades peninsulares en reemplazo del rey (Junta Central, Regencia, Cortes de Cádiz) y las in-

${ }^{18}$ Contra lo que se difundió intencionadamente en la península, el mexicano y otros casos contemporáneos, muestran que no era, como presumía la mente colonial, la separación del cuerpo hispano lo que perseguían aquellas juntas. Para ellas se trataba, por decirlo de modo más gráfico, de llegar a declaraciones de autonomía y no de independencia. Por ello el lenguaje apropiado era el legal y constitucional (Portillo Valdés, 2006, p. 81). 
justicias cometidas sobre territorios americanos por parte de estas autoridades ad-hoc, precipitaron, según la perspectiva de este letrado criollo, la necesidad de actuar. En el libro viII, Mier se encargó de enumerar las distintas medidas despóticas de la Regencia (parche arbitrario e insuficiente de la Junta Central) con el fin de justificar la erección de juntas locales americanas. Destacamos la causalidad inexorable que Mier estableció en este libro entre el proyecto defectuoso que llevó a cabo la Regencia en América con las inclemencias de una naturaleza revolucionaria: "los ánimos están exaltados, y es de temer que las materias combustibles que se van reuniendo y amontonando en estos senos políticos produzcan de repente volcanes inextinguibles" (Mier, 1990, libro viII, p. 233).

La analogía que configuró Mier entre los procesos revolucionarios asociados a inextinguibles inclemencias de la naturaleza se trató de un procedimiento narrativo propio del plan que utilizó el criollismo concebido como retórica de la restauración americana. Este procedimiento implicó la apropiación del concepto americanos por parte del sector criollo americano como sinónimo del nombre indianos, estipulando de esta forma una transformación estratégica sobre el mote denigrante de naturales con el que se caracterizaba en las Cortes de Cádiz a los americanos y su supuesta incapacidad política. Por otra parte, la apropiación de Mier con respecto al nombre indianos no se trató de un procedimiento novedoso en su escritura: la misma se destacó como procedimiento discursivo principal en su Sermón del 12 de diciembre de 1794 en honor a la Virgen de Guadalupe (Rosetti, 2012). En este sermón, que le valió el destierro de su patria, configuró un nosotros inclusivo complejo al considerar a los criollos representantes tanto de los americanos como de los naturales ${ }^{19} \mathrm{de}$ Nueva España: “¡Qué gloria para los indianos! [...] ¡Qué honra para nosotros!; ¡qué piadosa envidia para las demás naciones!, pero ¡qué satisfacción para la América" (Mier, 1982, p. 736).

La apropiación discursiva usada por Mier abrevó en fuentes heterogéneas como fueron la Brevísima relación de la destrucción de las Indias (1552) de Bartolomé de Las Casas, los Comentarios reales del Inca Garcilaso (1609), la Monarquía indiana (1615) de fray Juan de Torquemada, el Theatro de virtudes políticas (1680) de Carlos de Sigüenza y Góngora y la Historia antigua de México (1780-1781) de Francisco Javier Clavijero, entre otros. Estos escritos

${ }^{19} \mathrm{Al}$ respecto sostiene Cañizares Esguerra (2005): "Los criollos se vieron a sí mismos naturales de sus reinos locales y discriminaron a los peninsulares como extranjeros incapaces de amar y cuidar a las comunidades locales" (p. 433) (traducción mía). 
recuperaron la forma de vida previa a la conquista española y mostraron los logros civilizatorios de los imperios indígenas. ${ }^{20}$ Salvando las distancias entre las propuestas de cada una de las obras enumeradas, todas ellas anclaron su estudio en los aspectos culturales y económicos de los imperios azteca e inca y reflexionaron/cuestionaron la manera apropiada mediante la cual la monarquía española debía valorar estos tesoros antiguos como modelos que contribuyeron a la configuración del buen vasallo indiano.

Por otro lado, las obras mencionadas estipularon una división entre historia antigua y moderna de las Indias considerando a la conquista española como proceso dador de una nueva era. Si nos concentramos en el discurso criollo del siglo xVIII, de cara a reflexionar sobre el tratamiento particular que del mismo hizo Mier, se destacó una dependencia del modelo de historia cultural americana en relación con el paradigma europeo que construyeron las obras de los jesuitas exiliados en el siglo XVIII (Cañizares Esguerra, 2007; Portillo Valdés 2006). En relación con el trabajo de Clavijero, señala Portillo Valdés (2006):

$\mathrm{Al}$ analizar la aportación de Clavijero, nota David A. Brading, que el jesuita no trató de llevar a cabo una genérica reivindicación de las culturas americanas, sino de recrear en América una historia antigua similar a la europea, en la que aztecas e incas ocuparían el lugar de pueblos civilizados frente a un resto general de bárbaros. En efecto, el interés de Clavijero fue "europeizar" la historia antigua de América para así poder realizar atribuciones a los mexicanos precolombinos de aquellas virtudes políticas que se entendían exclusivas de los pueblos europeos [...] En suma, Clavijero estaba presentando una comunidad perfecta en la antigüedad mexicana, algo que no era posible estudiar ni conocer "en sus descendientes o en las naciones del Canadá y de la Luisiana" y que exigía una labor historiográfica que pasaba, como requisito previo, por expropiar a los indígenas de los instrumentos y materiales para la misma (p. 37).

El hecho de que los letrados criollos expropiaran a los indígenas los materiales e instrumentos para la consolidación de una historiografía con tintes europeos coincidió con el tipo de relato a lo indiano que construye Mier a lo largo de su historia novohispana. Es decir, la trama de la escritura histórica se plasmó en Mier a través de dos ejes bien claros: por un lado, el quiebre o

${ }^{20}$ Más allá de la lectura demoníaca que realizó Torquemada sobre las costumbres religiosas y sociales que movían a los aztecas en su vida cotidiana. 
fractura de la Carta Magna entre los conquistadores y la monarquía española; por otro lado, el descontento antiguo de los americanos por la opresión que padecían causada por el despotismo del gobierno peninsular.

El primer eje se ligaría a la violación de un derecho consagrado a los americanos criollos tendentes a obtener igualdad de condiciones que los españoles para el ejercicio de la autonomía política: "recurro para fijar el estado de la cuestión entre españoles y americanos a principios más sólidos y absolutamente incontestables: al pacto solemne y explícito que celebraron los americanos con los Reyes de España, que más claro no lo hizo nación alguna, y está autenticado en el mismo código de sus leyes. Ésta es nuestra magna carta" (Mier, 1990, libro xIV, pp. 475-476) ${ }^{21}$. Con el golpe armado de Gabriel Yermo (15 de septiembre de 1808), aceptado por la Regencia y por las posteriores Cortes de Cádiz, Nueva España perdió su posibilidad de procurar un cambio político dentro de los confines de la monarquía española. Esta irrupción armada, sostenida por los comerciantes peninsulares y gran parte de la Audiencia de Nueva España, generó un desvío sobre la constitucionalidad americana que pasó a dirimirse en la construcción discursiva-polémica de los debates públicos llevados a cabo en las sesiones de las Cortes de Cádiz y, sobre todo, en el diálogo entre los distintos periódicos que circulaban por Cádiz y por Londres. En palabras de Antonio Annino (2015):

La originalidad del dominico fue poner al centro de la cuestión constitucional la ilegitimidad del golpe más que la de la abdicación del rey. Con este desplazamiento de su eje central, la crisis se ubicaba y se originaba en el territorio novohispano otorgando una nueva y más fuerte legitimidad histórica al patriotismo criollo: el golpe, y no sólo la abdicación, rompió lo que Fray Servando llamó la Magna Carta de Nueva España frente a la Corona, dejando el reino libre de perseguir su destino. El golpe era ilegal porque atentaba en contra de la legítima retroversión de la soberanía reivindicada por el cabildo de Ciudad de México (pp. 29-30).

El planteo de Mier (1990) priorizó el grave desajuste legal de Nueva España que conllevó la creación de una contrainsurgencia articulada a tra-

21 "Todas, como se ve, son leyes remuneratorias anexas al pacto social de los americanos criollos con los Reyes, como que las consiguieron sus padres con pactos onerosos, y por consiguiente inalterables (Mier, 1990, libro xIV, p. 488). 
vés de informes militares y de las Gacetas del Gobierno: "[N]o sé qué admiré más, si la frescura con que se da parte de semejante atrocidad al Virrey, o la desvergüenza con que éste hace poner en las gacetas como digna de elogio tal barbaridad" (libro xII, p. 393). Este desajuste plasmado en la escritura pública quiso borrar la constitución que dieron los reyes a América mediante la cual se habían reconocido ciertos derechos de representación política que no tenían otros dominios de la monarquía en Europa:

Tal es la constitución que dieron los Reyes a la América, fundada en convenios con los conquistadores y los indígenas, igual en su constitución monárquica a la de España, pero independiente de ella. Uniéronse a Castilla; pero no como Andalucía y Galicia, sino con igual principado soberano, y conservando sus leyes, fueros y pactos; y deben regirse y gobernarse, como si el Rey que los tiene juntos fuese sólo Rey de cada uno de ellos, según hablan los mejores Jurisconsultos (libro XIV, p. 507).

Los convenios que Mier señaló entre los reyes y los conquistadores e indígenas le permitieron estipular en su escritura una lucha legal para que los americanos criollos pudiesen ser los representantes tanto de los indígenas como de las castas americanas. A su vez, la argumentación basada en un pacto o constitución originaria, propia de la conquista española, contribuyó a cimentar una legalidad americana en relación directa con el rey español, cuestionando la legitimidad de la constitución de las Cortes de Cádiz:

No, nuestro pacto social no puede ser variado si nuestro consentimiento, y nosotros ni lo hemos prestado por nuestros Diputados, que ni han sido llamados en el número correspondiente igual a su población como en España, y que ha protestado las Cortes y la Constitución los pocos que han venido; ni lo hemos prestado por nosotros mismos [...] En nuestro pacto invariable no hay otro soberano que el Rey. Si falta, la soberanía retrovierte al pueblo americano, que ni por sus leyes ni por sus declaraciones de ese mismo Congreso es súbdito de España sino su igual (libro xIV, p. 509).

Coincidimos con Antonio Annino (2008) quien sostiene que la propuesta de Mier no incitaba a una emancipación absoluta, sino que demandaba la revisión y reconocimientos de leyes ya promulgadas que no eran respetadas. Así, Mier caracterizó el constitucionalismo americano "revolucionario 
en el sentido tradicional de restaurar plenamente unas imaginarias libertades antiguas golpeadas por el "despotismo" regalista" (p. 30). Esta propuesta coincide con la de Anthony Padgen en lo que respecta a la concepción de Mier de los conceptos de revolución y restauración con un agregado fundamental: para Padgen (1990) la asimilación de estos dos conceptos era una característica propia del discurso criollista: "[L]os rebeldes no son "revolucionarios" en el sentido que se dio a esa palabra después de 1789, puesto que no están pidiendo ningún cambio radical en la estructura de la sociedad a la que pertenecen. Lo único que piden es la restitución del statu quo; la suya es una "revolución" en el sentido primitivo y más literal de la palabra" (p. 189).

\section{CONCLUSIÓN}

Servando Teresa de Mier escribió su obra en los años de 1810 a 1813, periodo álgido por la necesidad de implementar medidas jurídico-políticas que actuaran como un escudo protector frente a la invasión napoleónica, la ausencia del rey y las guerras internas en España y sus provincias americanas. Este periodo se vio articulado por la reconstrucción histórica del pasado de la monarquía española, "fue una necesidad [...] de pensarse históricamente para poder, posteriormente, pensarse políticamente [...] el resultado de incorporar los planteamientos iusnaturalistas, individualistas y liberales conllevó una revolución de dimensiones todavía inconmensurables" (Frasquet, 2012, p. 119).

La reflexión y escritura de la historia de la revolución novohispana llevó a Mier a establecer una concatenación entre el golpe de Estado que destituyó al virrey Iturrigaray en 1808 con los debates constitucionales de las Cortes de Cádiz y el proceso de insurgencia de ciertos sectores de la sociedad novohispana. Como bien lo destacó Rieu-Millan (1989), la perspectiva política de Mier fue "mexicanista": "México era el objeto primero de las actividades de Mier, aunque veía que su porvenir era solidario con el de todo el continente; de ahí la importancia de las noticias comunicadas por él sobre la situación política y militar del resto de América" (p. 63). La "solidaridad" que practicó este letrado novohispano consistió en apropiarse del concepto americanos y otorgarle un tratamiento flexible que le permitió torcer y adaptar la trama narrativa del discurso de ciertos sectores criollistas. Lo que a primera vista pudo verse como una divulgación benefactora y solidaria de noticias americanas, se trató de un plan discursivo minuciosamente pensado (aunque caóticamente 
plasmado en su escritura). Este plan de la trama histórica repensó las categorías de revolución americana y de americanos en conexión con una mirada cultural y económica (ligada a una tradición de reivindicación de los derechos criollos e indígenas frente al favoritismo por los advenedizos españoles). A su vez, dialogó con una denuncia bien clara de Mier y otros letrados criollos sobre el despotismo del gobierno peninsular sobre América y la necesidad de reconfigurar la representación política americana luego del quiebre o fractura de la Magna Carta, o pacto constitucional, causado por la vacancia del rey.

El plan de escritura de Mier debió enfrentarse con el desafío de reflexionar sobre una sociabilidad representativa imposibilitada en Nueva España a causa del golpe de 1808 y de las luchas intestinas entre la insurgencia y la contrainsurgencia realista. Al respecto, sostiene Annino (2008):

[L]a revolución que defendió fray Servando fue la del Cabildo y no la de Hidalgo, considerada una rebelión algo caótica y sin un programa definido, pero justificable por el golpe en contra de la verdadera revolución de 1808. La insurgencia no era para el dominico la revolución de Nueva España [...] La historia no es original por su ideología, claramente antiliberal, sino por su erudición documental, por la fuerza de su escritura y por el abanico de argumentaciones empleadas (pp. 30-31).

La observación de Annino debe ser puesta en tela de juicio si consideramos el minucioso trabajo de resignificacion que Mier realizó con respecto a la trama narrativa americana que ligó a una experimentación constante desde el laboratorio político-discursivo. Más que defender una revolución institucional ante otra insurgente y popular, el mérito de Mier residió en proponer, inventar, un archivo o memoria colectiva americana que vinculó los tiempos de la conquista española con los tiempos políticos y vertiginosos inaugurados a partir de 1808 y ampliar ese discurso a fin de abarcar a todos los sectores "desprotegidos" de América. Dentro de la trama que propuso Mier, no nos es posible escindir la búsqueda de la autonomía política americana de la insurgencia o los debates constitucionales. Estos tres hechos o momentos históricos fueron concebidos por Mier como eslabones en la compleja cadena de la construcción de representación política americana. 


\section{LISTA REFERENCIAS}

Adelman, J. (2008). An age of imperial revolutions. The American Historical Review, 13(2), 319-340. Recuperado de www.jstor.org/stable/30222842

Altuna, E. (2009). Retórica del desagravio. Estudios de cultura colonial peruana. Salta: Centro Promocional de Investigaciones en Historia y Antropología-Universidad Nacional de Salta.

Annino, A. (2008). 1808: el ocaso del patriotismo criollo en México. Historia y Política, 19, 39-73. Recuperado de https://recyt.fecyt.es/index.php/Hyp/article/view/44526

Annino, A. (2015). Revoluciones hispanoamericanas. Problemas y definiciones. En P. González Bernaldo de Quirós (dir.), Independencias iberoamericanas. Nuevos problemas y aproximaciones (pp. 37-52). Buenos Aires: Fondo de Cultura Económica.

Ávila, A. (2002). En nombre de la nación. La formación del gobierno representativo en México (1808-1821). México: Taurus/CidE.

Brading, D. (1980). Fray Servando Teresa de Mier. En Los orígenes del nacionalismo mexicano (trad. S. Loaeza Grave) (pp. 43-95). México: Ediciones Era.

Brading, D. (1991). Orbe indiano. De la monarquía católica a la República criolla 1492-1867 (trad. J. J. Utrilla). México: Fondo de Cultura Económica.

Brading, D. (2004). Introducción a Viscardo y Guzmán, Juan Pablo. En Carta dirigida a los españoles americanos. México: Fondo de Cultura Económica.

Breña, R. (2005). Pensamiento político e ideología en la emancipación americana. Fray Servando Teresa de Mier y la independencia absoluta de Nueva España. En F. Colom González (ed.). Relatos de nación. La construcción de las identidades nacionales en el mundo hispánico (pp. 73-102). Madrid-Frankfurt: Iberoamericana-Vervuert.

Breña, R. (2013). El imperio de las circunstancias. Las independencias hispanoamericanas y la revolución liberal española. México: El Colegio de México/Marcial Pons.

Breña, R. (2014). Algunas cuestiones historiográficas relevantes para el estudio de las revoluciones hispánicas y del proceso emancipador novohispano. En P. Gonzalbo Aizpuru y A. Lira González (coords.). México 1808-1821. Las ideas y los hombres (pp. 107-131). México: El Colegio de México.

Cañizares Esguerra, J. (1998). Spanish America in eighteenth-century European travel compilations: A new "art of reading" and the transition to modernity. Journal of Modern History, 2(4), 329-349.

Cañizares Esguerra, J. (2005). Racial, religious, and civic creole identity in colonial Spanish America. American Literary History, 17(3), 420-437. DoI: https://doi. org/10.1093/alh/aji024 
Cañizares Esguerra, J. (2007). Cómo escribir la historia del Nuevo Mundo. Historiografías, epistemologías e identidades en el mundo del Atlántico del siglo XVIII (trad. S. Moreno Parada, rev. por J. Cañizares Esguerra). México: Fondo de Cultura Económica.

Domínguez Michael, C. (2004). Vida de Fray Servando. México: Ediciones Era.

Entin, G. (2013). El patriotismo americano en el siglo XVIII. Ambigüedades de un discurso político hispánico. En V. Hébrard y G. Verdo (eds.), Las independencias hispanoamericas. Un objeto de la historia (pp. 19-34). Madrid: Casa de Velázquez.

Frasquet, I. (2012). Orígenes del primer constitucionalismo mexicano, 1810-1824. En A. Annino y M. Ternavasio (coords.), El laboratorio constitucional iberoamericano (pp. 115-134). Frankfurt-Madrid: AHILA-Iberoamericana-Vervuert.

Garriga, C. (2003). El derecho de prelación: en torno a la construcción jurídica de la identidad criolla. En XIII Congreso del Instituto Internacional de Historia del Derecho Indiano (pp. 1085-1128). San Juan: Oficina del Historiador Nacional de Puerto Rico-Library of Congress.

Garriga, C. (2006). Patrias criollas, plazas militares: sobre la América de Carlos IV. En E. Martiré (coord.). La América de Carlos IV (Cuadernos de Investigaciones y Documentos, I, pp. 35-130). Buenos Aires: Instituto de Investigaciones de Historia del Derecho.

Goren, Y. B. (2011). Servando Teresa de Mier. En V. Guedea (coord.), El surgimiento de la historiografía nacional (vol. III, pp. 65-92). (Historiografía mexicana, J. A. Ortega y Medina y R. Camelo, coords.). México: Universidad Nacional Autónoma de México.

Hutcheon, L. (1992). Ironía, sátira, parodia. Una aproximación pragmática a la ironía. En H. Silva (ed.), De la ironía a lo grotesco (pp. 173-193). México: Universidad Autónoma Metropolitana-Iztapalapa.

Lafuente Ferrari, E. (1941). El virrey Iturrigaray y los orígenes de la Independencia de Méjico. Madrid: Consejo Superior de Investigaciones Científicas-Instituto González Fernández de Oviedo.

Lempérière, A. (2008). Los hombres de letras hispanoamericanos y el proceso de secularización (1800-1850). En C. Altamirano (ed.), Historia de los intelectuales en América Latina (vol. I, pp. 242-266, J. Myers, ed.). Buenos Aires: Katz Editores.

Lomné, G. (2014). ¿La revolución en clave romana? Unos apuntes sobre la retórica americana de la libertad en las Cortes de Cádiz (1810-1814). En G. Lomné y S. O'Phelan (eds.), Voces americanas en las Cortes de Cádiz (1810-1814) (pp. 387-416). Lima: Institut Français d'Études Ándines/Pontificia Universidad Católica del Perú.

López Cancelada, J. (1811). La verdad sabida y buena fe guardada: origen de la espantosa revolución de Nueva España comenzada en 15 de setiembre de 1810. Defensa de su fidelidad. Cuaderno primero... México: Documentos publicados en la Gazeta de México. 
Mier, fray S. T. de (1945). Escritos y memorias (pról. y selección E. O’ Gorman). (Biblioteca del Estudiante Universitario, 56). México: Universidad Nacional Autónoma de México.

Mier, fray S. T. de (1982). Sermón guadalupano. En E. de la Torre Villar y R. Navarro de Anda (comps.), Testimonios históricos guadalupanos (pp. 730-757). México: Fondo de Cultura Económica.

Mier, fray S. T. de (1990). Historia de la revolución de la Nueva España antiguamente Anáhuac o verdadero origen y causas de ella con la relación de sus progresos hasta el presente año de 1813 (edición crítica). A. Saint-Lu, M.-C. Bénassy-Berling (coords.) (pref. D. Brading). París: Publications de La Sorbonne.

Moreno Gutiérrez, R. (2004). La idea de América al tiempo de la independencia. Nueva España, 1808-1821. (Tesis de Licenciatura). Universidad Nacional Autónoma de México, México.

Moreno Gutiérrez, R. (2015). Blanco White, Mier y Walton en la Carta de Jamaica: las primeras historias de la revolución de la Nueva España. Boletín de la Academia Nacional de la Historia, XCVIII(392), 31-62.

O'Gorman, E. (1981). Estudio preliminar a Servando Teresa de Mier. En Obras completas, I: El heterodoxo guadalupano. (Nueva Biblioteca Mexicana, 81). México: UnAm. Padgen, A. (1990). El imperialismo español y la imaginación política. Barcelona: Planeta. Paniagua, J. (2007). Introducción. En Pedro Batista Pino-Juan López-Cancelada. Exposición suscinta y sencilla de la Provincia del Nuevo México y otros escritos (ed., intr., notas, glosario e índices J. Paniagua). (Colección Tradición Clásica y Humanística en España e Hispanoamérica). León: Junta de Castilla y León/Universidad de León.

Paniagua, J. (2008). Introducción. En Juan López Cancelada (ed.), El Telégrafo Americano (10 de octubre de 1811-31 de marzo de 1812) [Facsímil, 1812]. (ed., intr., notas e índices J. Paniagua). (Colección Tradición Clásica y Humanística en España e Hispanoamérica). León: Junta de Castilla y León/Universidad de León.

Pasino, A. (2010). Los escritos de Manuel J. Quintana y José M. Blanco White en el Semanario Patriótico (1808-1810); sus aportes a la construcción del lenguaje del primer liberalismo español. Anuario del Centro de Estudios Históricos "Prof. Carlos S. A. Segreti”, 10(10), 343-363.

Portillo Valdés, J. M. (2006). Crisis atlántica. Autonomía e independencia en la crisis de la monarquía hispana. Madrid: Fundación Carolina/Centro de Estudios Hispánicos e Iberoamericanos/Marcial Pons/Ediciones de Historia, S. A.

Quexas de los Americanos (1812). Cádiz: Imprenta de la Junta de Provincia, en la Casa de Misericordia (sin datos de autor). 
Rieu-Millan, M. L. (1982). Une lettre inédite de Fray Servando Teresa de Mier (1810). Cahiers du Monde Hispanique et Luso-Brésilien (Caravelle), 39, 65-73.

Rieu- Millán, M. L. (1989). Fray Servando de Mier en Londres y Miguel Ramos Arispe en Cádiz (su actividad política y propagandística según una carta inédita de Mier, 1812). Suplemento de Anuario de Estudios Americanos, Sección de Historiografía y Bibliografía, 46(2), 55-73.

Rodríguez O., J. E. (1988). Introducción. En S. Teresa de Mier, Obras completas, vol. IV: La formación de un republicano. México: UNAM.

Rojas, R. (2003). La escritura de la independencia. El surgimiento de la opinión pública en México. México: Taurus/Cide.

Rosetti, M. (2012). Lecturas que ilustran, lecturas que desgarran. Fray Servando Teresa de Mier y su mirada criollista de la tradición guadalupana. Armas y Letras, 15(81), 27-32. Recuperado de http://www.armasyletras.uanl.mx/81/7_lecturas.pdf

Rosetti, M. (2014). La práctica de la libertad civil: la polémica de Servando Teresa de Mier y José Blanco White en la fragmentación de la monarquía española. Dieciocho, 37(2), 295-319. Recuperado de https://faculty.virginia.edu/dieciocho/37.2/

Rosetti, M. (2016). Servando Teresa de Mier y sus polémicas cartas a la Ilustración española. Orbis Tertius, 21(24). Recuperado de https://www.orbistertius.unlp.edu. ar/article/view/OTe015

Torres Puga, G. (2013). La transformación de la Gazeta de México, 1805-1808. En M. A. Landavazo Arias y M. Guzmán Pérez (eds.). Guerra, política y cultura en las independencias hispanoamericanas (pp. 21-58). Morelia: Universidad Michoacana de San Nicolás de Hidalgo/El Colegio de Jalisco.

Villoro, L. (1977). El proceso ideológico de la revolución de independencia. México: Universidad Nacional Autónoma de México.

White, H. (2003). El texto histórico como artefacto literario y otros escritos (intr. V. Tozzi, trad. V. Tozzi y N. Lavagnino). Barcelona: Paidós.

Zárate Toscano, V. (1986). Juan López-Cancelada. Vida y obra. (Tesis de maestría inédita). Universidad Nacional Autónoma de México, México.

Zárate Toscano, V. (2010). Con la pólvora en el tintero. Juan López de Cancela y la independencia novohispana. En L. Suárez de la Torre (coord.), Creación de estados de opinión en el proceso de independencia mexicano (1808-1823) (pp. 195-228). México: Instituto Mora. 